\title{
9: $97825196-97857776$
}

National Cancer Institute

\section{Source}

National Cancer Institute. 9: 97825196-97857776. NCI Thesaurus. Code C41693.

Physical location of ANP32B_Gene 